\title{
Federally Owned Coal, Federal Lands, and Coal Quality in the Colorado Plateau Region
}

Federally owned coal plays a major role in the energy supply of the United States. About 1.1 billion tons of coal were produced in the United States in 1997 (U.S. Department of Energy, 1998). About 30 percent of that total, or about 330 million tons, ${ }^{1}$ came from Federal lands. (See USGS Fact Sheet FS-012-98.) Almost all of the Federal coal production is from Wyoming, Montana, and three States in the Colorado Plateau region-Utah, Colorado, and New Mexico ${ }^{2}$ (see table below).

\begin{tabular}{|c|c|}
\hline \multicolumn{2}{|c|}{$\begin{array}{l}1997 \text { Federal Coal Production from States } \\
\text { in the Colorado Plateau Region } \\
\text { (in thousands of short tons) }\end{array}$} \\
\hline Utah & 23,887 \\
\hline Colorado & 22,264 \\
\hline New Mexico & 6,029 \\
\hline TOTAL for Region & 52,180 \\
\hline
\end{tabular}

(U.S. Department of Energy, 1998, p. 21)

The National Coal Resource Assessment, a multi-year effort by the U.S. Geological Survey, included studies of federally owned coal in seven areas (called "priority assessment units") in the Colorado Plateau region (see CDROM by Kirschbaum and others, 2000). The goal of the assessment was to identify and characterize major coal resources that will supply the Nation's energy needs during the first quarter of the 21st century, and, likely, well beyond.

This Fact Sheet presents resource estimates, never before calculated, for Federal coal in the seven priority assessment units in Utah, Colorado, and New Mexico. More than 360 billion tons of Federal coal exist in these areas. Knowing where the Federal coal is located, how much Federal coal exists, and its geologic setting helps land managers, planners, and mineral developers to make informed land-use decisions.

The Colorado Plateau region has extensive coal-bearing areas (fig. 1) and approximately 40 active coal mines that supply fuel for many of the region's electrical power plants. Colorado Plateau coal is high in calorific value (Btu/lb), low in sulfur content, and contains few elements of environmental concern (see CD-ROM by Kirschbaum and others, 2000). From figures 1 and 2, we see that coal-bearing areas occur beneath lands administered by the Department of the Interior's Bureau of Land Management (BLM) and National Park Service (NPS), or the Department of Agriculture's U.S. Forest Service (USFS).

Additionally, coal is present beneath Tribal, State, and private lands in the Colorado Plateau region.

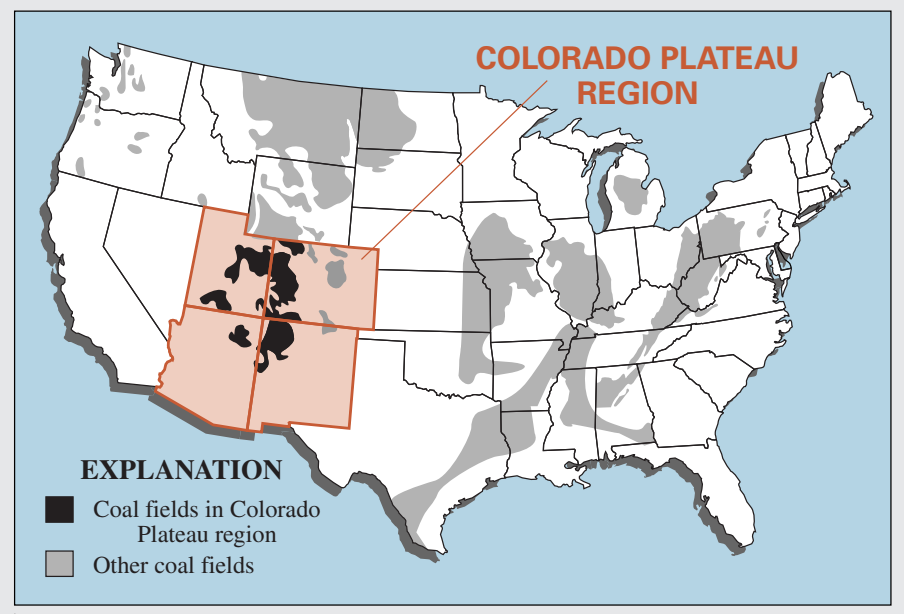

1 All tonnage values in this Fact Sheet are in short tons.

2 Arizona coal production is not from federally owned coal resources and thus is not included in this discussion.

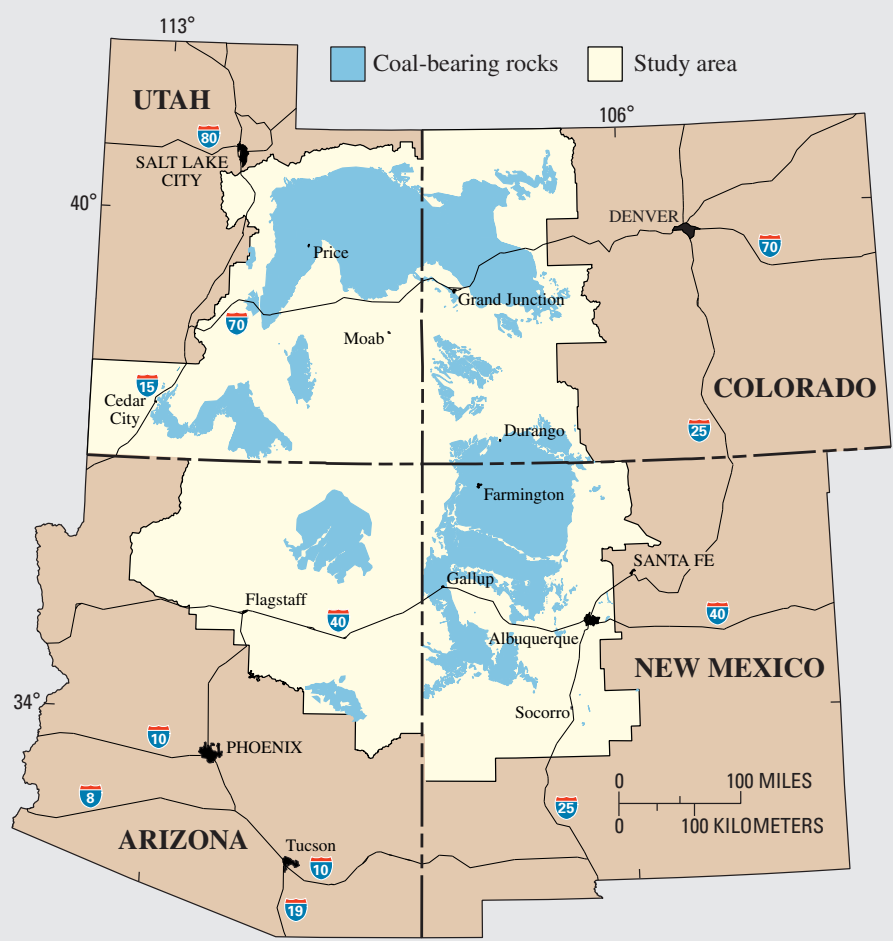

Figure 1 (above). Index map of Colorado Plateau region showing study area, coal-bearing areas, major towns, and roads.

Figure 2 (below). Land status in the Colorado Plateau region.

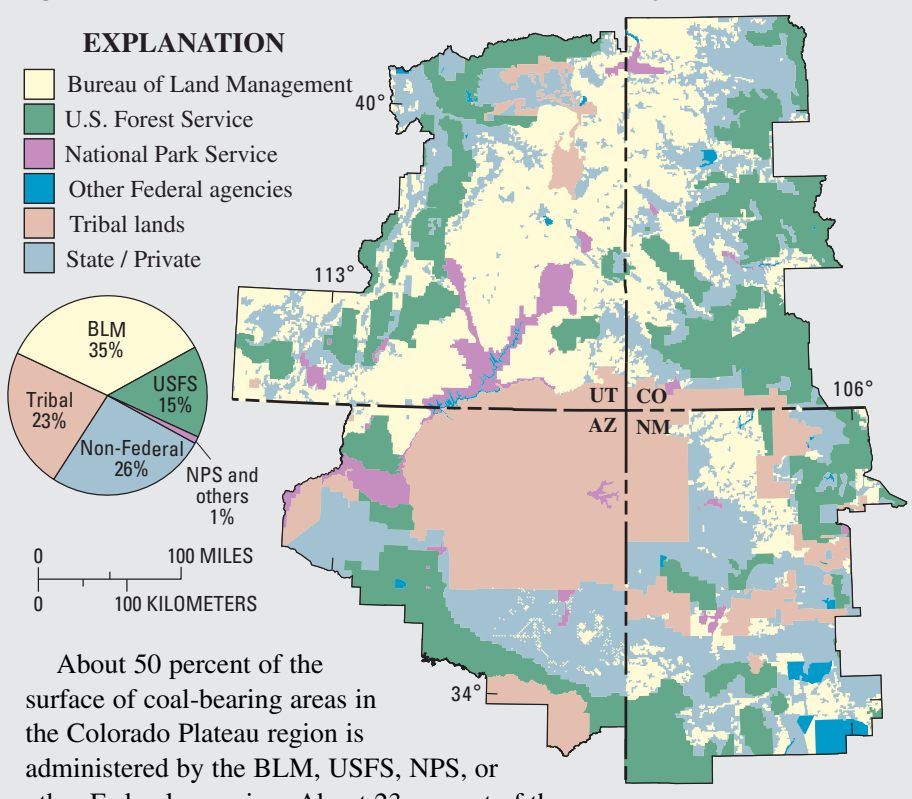

other Federal agencies. About 23 percent of the area

consists of Tribal lands; although those lands are held in trust by the U.S. Government, they are not considered Federal lands and their coal resources are not included in this study. About 26 percent of the region is administered by State agencies or is privately owned. 


\section{Federal coal resources}

It is important for land managers, planners, and mineral developers to know where the Federal coal
is located and how much Federal coal exists, in order to make informed land-use decisions.

For the seven priority assessment units studied in the Colorado Plateau as part of the National Coal

Resource Assessment, we identified Federal and non-Federal surface ownership and coal ownership,

\section{.}

Deserado assessment unit

Percent land surface managed
by the Federal Government:

Percent of assessment uni

Perlatin by federally owned coal: 99

Federal coal tonnage: 360 million tons

Percent of total coal tonnage
that is federally owned:

Coal Quality
Median values on as-receir

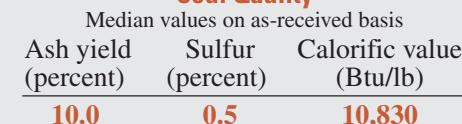

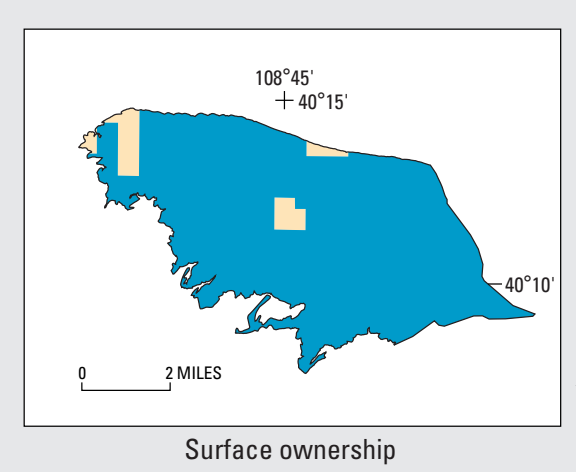

wnership

Federal

Non-Federal

Non-Federal
(State, Tribal, and private)
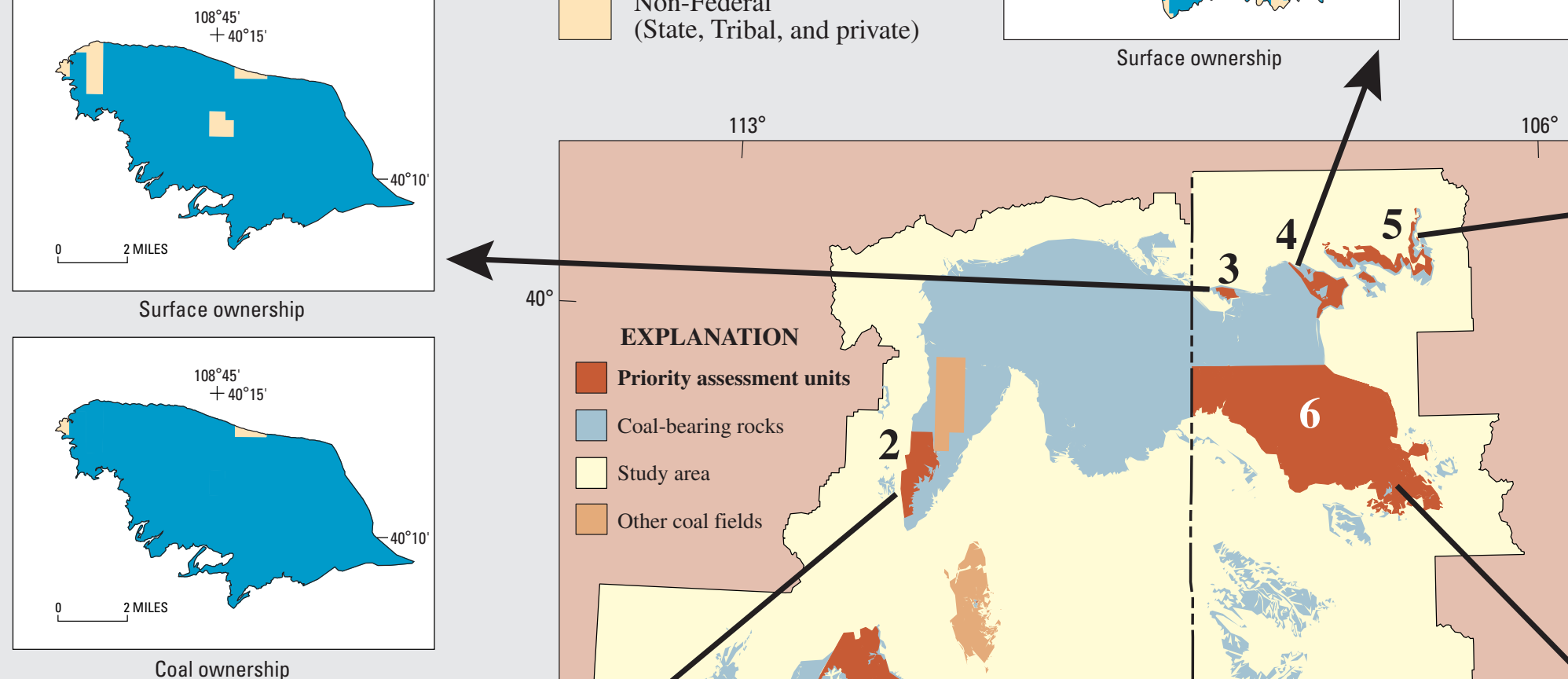

2 Southern Wasatch Plateau assessment unit

Percent land surface managed
by the Federal Government:

by the Federal Government:
Percent of assessment unit
underlain by federally owned coal: 96

Federal coal tonnage: 6.5 billion tons

Percent of total coal tonnage
that is federally owned:

hat is federally owned:

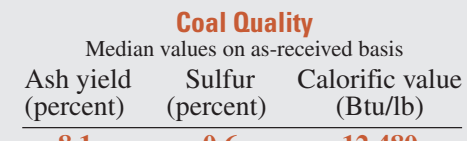

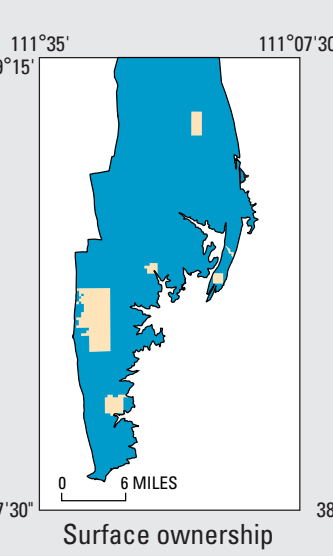

(1)

Kaiparowits Plateau assessment unit

Percent land surface managed
by the Federal Government:

Percent of assessment unit
underlain by federally owned coal: 99

Federal coal tonnage: 61 billion tons

Percent of total coal tonnage
that is federally owned:

Coal Quality
Median values on as-receies

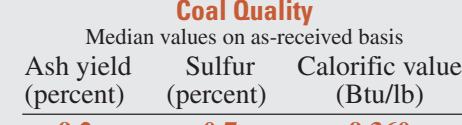

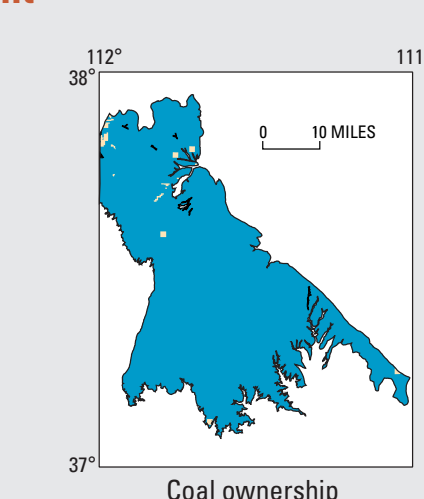

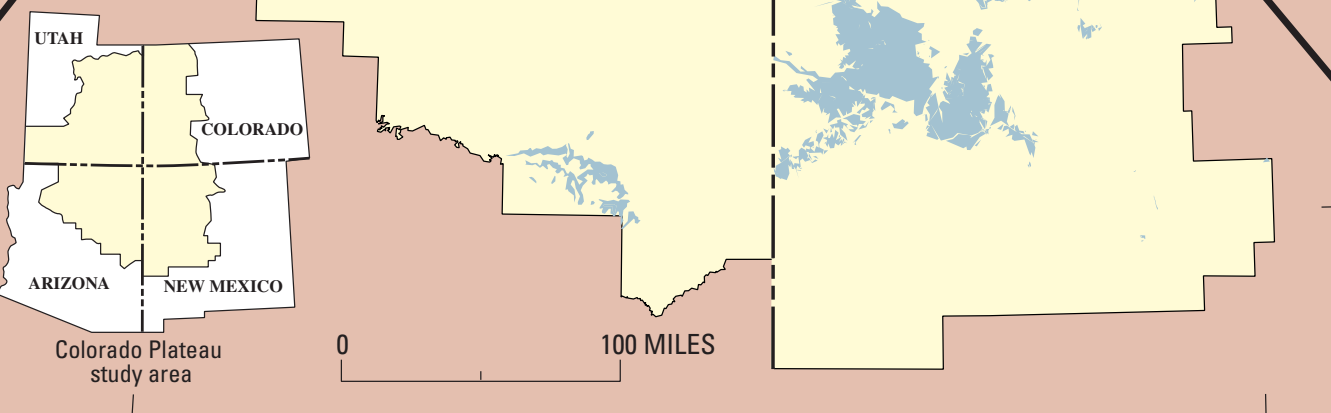

The seven priority assessment units of the Colorado Plateau region

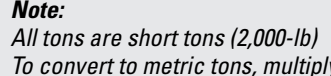
To convert to metric tons, multiply by 0.907
To convert feet to meters, multiply by 0.3048
To conerte

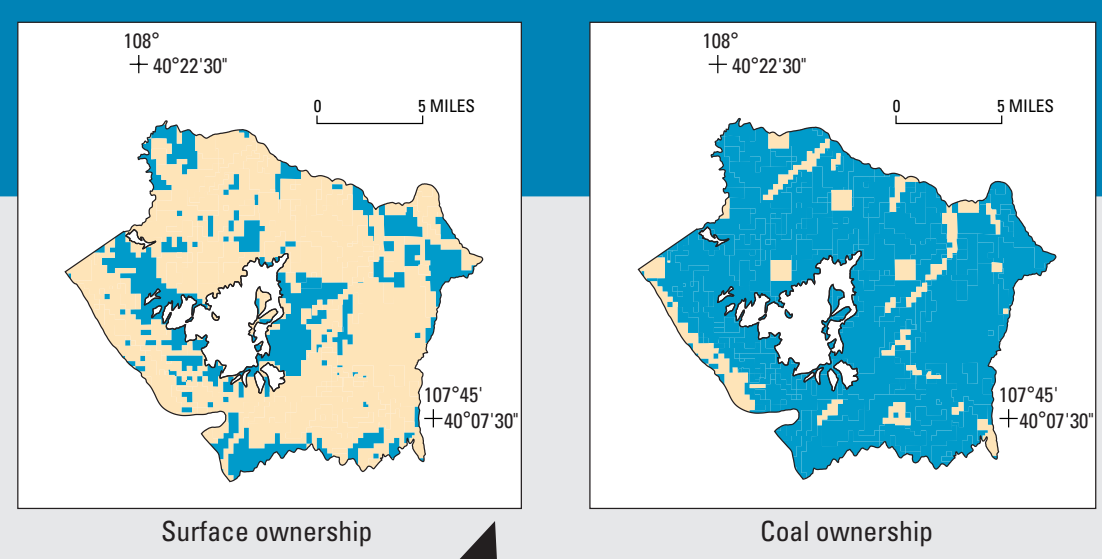

4 Danforth Hills assessment unit Percent land surface managed
by the Federal Government:

Percent of assessment unit
underlain by federally owned coal:

Federal coal tonnage: 18 billion ton Percent of total coal tonnage
that is federally owned: Caal Quality
Median values on as rece $\begin{array}{ll}\begin{array}{c}\text { Median values on as-received basis } \\ \text { Calorific value } \\ \text { Ash yield } \\ \text { (percent) }\end{array} & \begin{array}{c}\text { Sulfur } \\ \text { (percent) }\end{array} \\ \text { (Btu/lb) }\end{array}$

Yampa assessment unit Percent land surface managed
by the Federal Government:

Percent of assessment unit
underlain by federally owned coal: 65 Federal coal tonnage: 52 billion tons Percent of total coal tonnage
that is federally owned: Coal Quality
Median values Ona

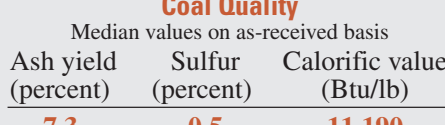
40 (n) Coal ownership

6 Southern Piceance Basin assessment unit

Percent land surface managed
by the Federal Government: Percent of assessment unit Federal coal tonnage: 94 billion tons Percent of total coal tonnage
that is federally owned:

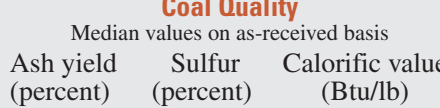
Coal ownership

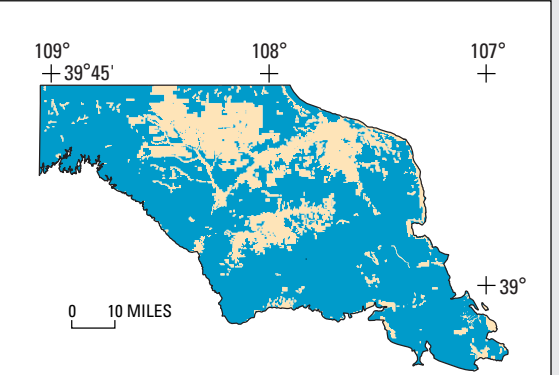

$7 \stackrel{\text { San Juan Basin }}{\text { assessmentin }}$ assessment unit Percent land surface managed
by the Federal Government: Percent of assessment Percent of assessment unit Federal coal tonnage: 130 billion tons Percent of total coal tonnage
that is federally owned:

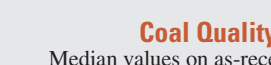

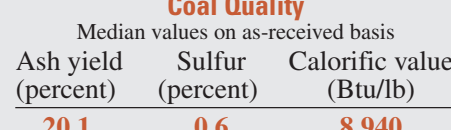


The U.S. Geological Survey's digital database of surface and coal ownership (USGS Fact Sheet FS-012-98) and data on coal resource tonnages (see center pages) become the basis for answering complex spatial queries when combined with information on coal quality, coal thickness, structure, and other parameters generated from geologic investigations. Integrating this information assists policy makers and planners in decisions concerning multiple use of Federal lands and coal resource development.

The table below shows statistics concerning Federal land and federally owned coal in each of the seven priority assessment units of the Colorado
Plateau. In these seven assessment units, federally owned coal tonnage was calculated for the first time as part of this study. Land area that is federally administered ranges from 7 to 99 percent; area underlain by Federal coal ranges from 54 to 99 percent; and coal tonnage that is federally owned ranges from 58 to 99 percent.

For the resources reported in this table, all coal is less than $6,000 \mathrm{ft}$ deep and is bituminous in rank; and coal beds included are $1.2 \mathrm{ft}$ thick or greater. Areas currently under Federal or State leases and areas being mined were excluded from our resource calculations for reasons of confidentiality.

\begin{tabular}{|c|c|c|c|c|}
\hline PRIORITY ASSESSMENT UNITS & $\begin{array}{l}\text { FEDERAL LAND AREA } \\
\text { (Percent of the surface } \\
\text { that is administered by } \\
\text { the Federal } \\
\text { Government) }\end{array}$ & $\begin{array}{l}\text { FEDERAL COAL AREA } \\
\text { (Percent underlain by } \\
\text { federally owned coal) }\end{array}$ & $\begin{array}{l}\text { FEDERAL COAL PERCENTAGE } \\
\text { (Tonnage that is } \\
\text { federally owned) }\end{array}$ & $\begin{array}{c}\text { FEDERAL COAL TONNAGE } \\
\text { (In millions of short tons } \\
\text { rounded to } \\
\text { two significant figures) }\end{array}$ \\
\hline Danforth Hills & 25 & 89 & 86 & 18,000 \\
\hline Yampa & 7 & 65 & 69 & 52,000 \\
\hline San Juan Basin & 41 & 54 & 58 & 130,000 \\
\hline Southern Piceance Basin & 64 & 74 & 79 & 94,000 \\
\hline Deserado & 94 & 99 & 98 & 360 \\
\hline Southern Wasatch Plateau & 94 & 96 & 96 & 6,500 \\
\hline Kaiparowits & 99 & 99 & 99 & 61,000 \\
\hline
\end{tabular}

About 71 percent ( 360 billion tons) of the total 510 billion tons of coal in the seven combined Colorado Plateau assessment units is federally owned (fig. 3). About 48 percent of the total 510 billion tons of coal in the assessment units occurs beneath federally managed land surface; the rest of the coal occurs beneath State, Tribal, or privately owned land.

The federally owned coal deposits of the Colorado Plateau region play an important role in supplying energy to our Nation. About 360 billion tons of Federal coal exist in the seven Colorado Plateau assessment units studied for the National Coal Resource Assessment. As United States coal resources continue to be examined for potential development, there is sustained interest in Federal coal in the Colorado Plateau region.



Figure 3. Total coal tonnages according to ownership categories, Colorado Plateau region.

\section{References Cited}

Kirschbaum, M.A., Roberts, L.N.R., and Biewick, L.R.H., eds., 2000, Geologic Assessment of Coal in the Colorado Plateau-Arizona, Colorado, New Mexico, and Utah: U.S. Geological Survey Professional Paper 1625-B, CD-ROM, 1175 .

U.S. Department of Energy, Energy Information Administration, 1998, Coal Industry Annual, 1997: DOE/EIA-0584(97).

U.S. Geological Survey Fact Sheet FS-012-98 (http://geology.cr.usgs. gov/pub/fact-sheets/fs-0012-98): Federal coal in the United States-A digital database of coal ownership status, $6 \mathrm{p}$.

For further information on Federal coal resources, contact:

$\begin{array}{lll}\text { Carol L. Molnia } & \text { clmolnia@usgs.gov } & \text { (303) 236-7769 } \\ \text { Laura N.R. Roberts } & \text { lroberts@usgs.gov } & \text { (303) 236-7777 } \\ \text { Laura R.H. Biewick } & \text { lbiewick@usgs.gov } & \text { (303) 236-7773 }\end{array}$

For further information on coal quality, contact:

Ronald H. Affolter affolter@usgs.gov

(303) 236-7752

For information on the geology of the priority assessment units, contact:

Michael E. Brownfield mbrownfield@usgs.gov (303) 236-7767 (Deserado and Danforth Hills)

Russell F.Dubiel_rdubiel@usgs.gov (Southern Wasatch Plateau)

James E. Fassett

jfassett@usgs.gov

(303) $236-1540$ (San Juan Basin)

(303) 236-0609

Robert D. Hettinger rhettinger@usgs.gov

(Kaiparowits Plateau and Southern Piceance Basin)

(303) $236-7770$

Edward A. Johnson_ ejohnson@usgs.gov

(303) $236-4857$

(Yampa)

U.S. Geological Survey, P.O. Box 25046,

Denver Federal Center, MS 939, Denver, CO 80225

This fact sheet can be viewed on the Web at:

http://geology.cr.usgs.gov/pub/fact-sheets/fs-011-01

For more information on the geology and coal resources of the Colorado Plateau, see the CD-ROM by Kirschbaum and others (2000) in References Cited above. 